\title{
Analysis of the Russian Economy's Ability to Generate Profit
}

\author{
Smirnov V.V. \\ Department of Industrial Economics \\ I.N. Ulyanov State University, \\ Cheboksary, Russia \\ walera712006@mail.ru
}

\author{
Osipov D.G. \\ Life safety and engineering ecology Department \\ I.N. Ulyanov State University, \\ Cheboksary, Russia \\ denps@mail.ru
}

\author{
Gorbunova P.G. \\ Department of Industrial Economics, \\ I.N. Ulyanov State University, \\ Cheboksary, Russia \\ polina7103@mail.ru
}

\begin{abstract}
Study subject is the ability of the Russian economy to generate profit. The aim of the work is to determine the key indicators affecting the ability of the Russian economy to generate profit. The study is based on a systematic approach using statistical, cluster, neural network and non-parametric analysis. The article explains the necessity for assessment of the Russian economy's ability to generate profit in the conditions of falling global trade rates and intensification of global competition and global economy transfer from total globalization policy to segmented American corporate governance. Scientific knowledge of system analysis as an aggregate of hierarchically ordered economic phenomena related to increase of economic growth rates, reduction of unemployment, general price level and interest rate, fine balance of state budget and trade balance, etc. became a methodological basis. As a result of analysis of an aggregate of retrospective and forecast economic indexes of Russia according to the data of the World Bank, International Monetary Fund, Organization for economic cooperation and development there have been revealed its abilities to generate profit due to change of: GDP deflator, value added (services), employment (services), FDI stocks (imports and exports), imports of goods and commercial services, FDI flows (imports), consumer prices, public sector expenditures, growth rates of total reserves (including gold), productivity growth rates, trade of goods and unemployment rate. The main factors constraining profit generation are: low performance indicators of industry, services and agriculture, trade activity; weak dynamics of foreign direct investment; insufficient liberalization of the Russian market against the background of stable growth of the corruption perception index. The ability of the Russian economy to generate profits in relation to low efficiency of industry, services, agriculture, steady dependence of productivity growth from growth of GDP deflator, short-term increase in general reserves, lack of liberalization of the Russian market and growth of the corruption perception index would not allow to avoid deep fall during the global recession.
\end{abstract}

\section{CCSCONCEPTS}

- Ability of the Russian economy to generate profit $\rightarrow$ statistical, cluster, neural network and non-parametric analysis $\rightarrow$ data from the World Bank, the International monetary Fund, the Organization for economic cooperation and development $\rightarrow$ the main factors constraining generation of profit $\rightarrow$ deep fall of the Russian economy during the global recession.

Keywords-generation of profit; changes; retrospective and forecast economic indicators; recession; system analysis; stagnation; factors.

\section{INTRODUCTION}

In the conditions of the world economy transition from the total globalization policy to the segmented American corporate governance (principal shareholder - USA) it is necessary to clarify the place of The Russian economy in this process. Understanding of the Russia current position would allow to define it as an "insider or outsider" without illusions and thus to choose effective and acceptable development guidelines.

The main criterion of the Russia's abilities to take active part in the process of American corporate governance is the ability of the Russian economy to generate profit.

The sharp fall of the Russian economy and its transition first to the stage of stagnation in 2013-2014 [1] and then to recession in 2015 [2] accompanied by negative processes of stagflation increasingly determines its place as the "backyard" of the world economy $[3,4]$.

Sluggish focus on restoring economic growth and generating resources for solving the task of structural transformation of the economy through 2017 - 2025, namely active transition to investment growth which will provided structural and technological modernization involving a significant increase in efficiency of production, increase of competitiveness of the Russian economy and building the capacity for export expansion (on the basis of formation of "new" income) will not allow Russia to leave the "backyard" soon.

Calculations made by Russian scientists shown that increase in funding of the new economy in comparison with other sectors leads to GDP growth by 4.45 percentage points during 7 years in 
show that almost any monetary infusion into the real sector of economy leads to an increase in GDP due to significant demonetization of the Russian economy [5]. This situation is of particular interest for studying of the GDP growth sources in the modern structure of Russian macroeconomics, its priorities and "insider or outsider" position in the new world order.

\section{LITERATURE REVIEW}

Analysis of economy ability to generate profit is based on the essence of economic science. It studies functioning of economy as a whole, the economic system as a whole, as a set of economic phenomena [6]. Assessment of economy's ability to generate profit is associated with building a hierarchy of economic problems diverse solutions - increase of economic growth; reduction of unemployment, overall price level and interest rate; balancing of state budget and trade balance [7, 8]. In accordance with this hierarchy there are determined the priorities of the national economy structure that can result in maximum generation of profit [9].

In the conditions of global trade rate falling and intensification of global competition it is becoming relevant to determine an economy's ability to generate profit that ensures stability of country's economy and improves quality of economic structures. Reliable labor and product markets and business conditions increase resistance to adverse shocks and reduce frequency of crises in general. In presence of a general shock a country with a weak economic structure may suffer up to twice the average loss of production in a given year compared to a more adaptable economy. From a policy perspective this means the need for implementation of structural policy in countries with lower quality of economic structures to increase resistance in the event of future shocks [10].

For Russia as an actively developing country creating new jobs and promoting economic development the problem of realizing the full potential of the economy to generate profit including through possible structural reforms becomes urgent. Identification of the Russian economy's ability to generate profit is an urgent problem as it could inform the country's policy makers about the options of policy implementation to promote economic growth and development [11].

Russia is actively involved in world economic relations occupying quite high places in international rankings. Economic development leads to a certain positive dynamics GDP, global investment index, doing Business rating [12]. However, some indicators deserve to be taken more seriously. This applies to services, capital outflow, attracting foreign investments, increasing the role and importance of Russia in international organizations.

Formation of foreign investments system of stable inflow, reduction of their outflow, amnesty of withdrawn capital as well as the process of deoffshorization of international transactions, decision to regulate the movement of capital flows is currently almost impossible without improving the investment climate $[13,14,15]$.

Choice of the Russian economy's ability analysis problem to generate profit is associated with the primacy of guidelines of the level system "state - region - enterprise" connected by stable relations and correcting the processes of production, distribution, exchange, consumption at the macro-, meso- and micro- level. At the same time the problem of forming and building up close and diverse interrelations and connectivity of socio-economic space is being solved.

\section{METHODOLOGY}

Analysis of the Russian economy ability to generate profit is associated with a retrospective and forecast assessment of dynamics (using the least squares method) of a set of indicators according to the World Bank, the International Monetary Fund, the Organization for Economic Cooperation and Development: per capita GDP growth rates; consumer prices; GDP deflator; unemployment rates; labor productivity growth rates; value added and employment in agriculture, industry and services; imports and exports of goods and commercial services; trade in goods and commercial services; current account balance; foreign direct investment (inflowoutflow) flows and stocks; balance sheet efficiency (flows/stocks); S\&P (global stock indices); growth rates of total reserves (including gold); public sector income and expenditure; public sector tax revenues, public sector surplus/deficit; public sector cash flow indices; ease of doing business and perception of corruption.

There is done a statistical and structural analysis using IBMSPSS Statistics software package. Statistical analysis in the form of selection method, study and presentation of large amounts of data for the main patterns and trends in the dynamics of the Russian economy.a certain phenomenon. Statistical analysis includes: data collection with subsequent mathematical processing; use of a particular piece of data according to certain criteria (stratified, cluster, quota, etc.); determining the relationship between the data and the reasons data is dependent from each other; identification of strength, intensity and frequency changes of objects and phenomena.

Cluster analysis is a multi-dimensional statistical procedure for collecting data containing information about the selection of objects and ordering the objects of study in relatively homogeneous groups. Cluster analysis allows you to develop a typology or classification of objects or phenomena; to identify the main scheme of objects (phenomena) grouping; to formulate hypotheses based on the study of data; to test a hypothesis or study in order to determine eligibility of existence of group selected in one way or another from the available data, etc.

Neural network analysis is usually used when there is a large amount of data. That is so because it is associated with construction of neural networks that recognize patterns and learn in the process to identify them better. In this instance the resulted ideas can contribute forecasts. These forecasts are then tested and used to test options of decision-making improvement.

Non-parametric analysis includes descriptive statistics and statistical input. Non-parametric analysis in the meaning of statistics over data is defined as a function over samples, doesn't depend on a parameter which interpretation doesn't depend on the whole corresponding to any parametrized distributions. Non-parametric statistical hypotheses pay attention to behavior of observed random variables. Non- 
parametricity value covers the methods that do not assume that model structure is fixed and that model size increases as data complexity growth.

\section{RESULTS}

Analysis of retrospective and forecast dynamics using the least squares method according to World Bank and the International Monetary Fund [16] data, aggregated indicators (GDP growth rates per capita, consumer prices, GDP deflator, unemployment rate, productivity growth rates) (Table I).

\section{TABLE I. AGGREGATED INDICATORS, 2000-2020.}

\begin{tabular}{|c|c|c|c|c|}
\hline Indicators & $\begin{array}{c}\text { Average, } \\
\text { AV }\end{array}$ & $\begin{array}{c}\text { Median, } \\
\text { Me }\end{array}$ & $\begin{array}{c}\text { Standard } \\
\text { deviation, } \\
\text { SD }\end{array}$ & $\begin{array}{c}\text { Dispersion, } \\
6^{2}\end{array}$ \\
\hline $\begin{array}{c}\text { Population growth } \\
\text { rate (annual, \%) }\end{array}$ & -0.15 & -0.17 & 0.28 & 0.08 \\
\hline $\begin{array}{c}\text { Per capita GDP } \\
\text { growth rate (per year, } \\
\% \text { ) }\end{array}$ & 5.95 & 5.29 & 9.05 & 81.87 \\
\hline $\begin{array}{c}\text { Consumer prices (\%) } \\
\text { per annum) }\end{array}$ & 11.87 & 11.65 & 4.98 & 24.78 \\
\hline $\begin{array}{c}\text { GDP deflator (annual, } \\
\% \text { ) }\end{array}$ & 14.96 & 15.17 & 8.41 & 70.75 \\
\hline $\begin{array}{c}\text { Unemployment rate, } \\
\text { total (\% of total labor } \\
\text { force) }\end{array}$ & 6.94 & 7.00 & 1.52 & 2.30 \\
\hline $\begin{array}{c}\text { Labor productivity per } \\
\text { employed person } \\
\text { (PPP, constant prices, } \\
\text { 2011, USD) }\end{array}$ & 103.62 & 104.39 & 3.92 & 15.39 \\
\hline \multicolumn{2}{|l|}{} & & & \\
\hline
\end{tabular}

Analysis revealed consistently low values of unemployment rate and growth rate of labor productivity. One of the factors constraining growth of unemployment in The Russian economy is the low level of labor productivity. The most sensitive to growth rate of labor productivity is the growth rate of GDP per capita which was most clearly manifested during the crisis in economy in $2008-2009$ and 2014 - 2015. Periods of productivity growth are associated with the growth of consumer prices and GDP deflator including by reducing the purchasing power (security) of the national currency.

Relatively high volatility of GDP growth per capita and GDP deflator is a consequence of stable consumer price dynamics high values.

Structure effectiveness. Analysis of the Russian economy structure efficiency is associated with assessment of retrospective and forecast dynamics of the value added relations in agriculture, industry, services to the relevant industry employment (Table II).

\section{TABLE II. THE EFFECTIVENESS, 2000-2020}

\begin{tabular}{|l|l|l|l|l|}
\hline Indicators & $\mathrm{AV}$ & $\mathrm{Me}$ & $\mathrm{SD}$ & $6^{2}$ \\
\hline Value Added, Agriculture (\% of GDP) & 4.36 & 4.13 & 0.89 & 0.79 \\
\hline Value Added, Industry (\% of GDP) & 30.44 & 30.05 & 1.57 & 2.48 \\
\hline Value Added, Services (\% of GDP) & 52.66 & 53.12 & 2.51 & 6.29 \\
\hline $\begin{array}{l}\text { Employment, agriculture (\% of total } \\
\text { employment) }\end{array}$ & 9.15 & 8.64 & 2.30 & 5.30 \\
\hline $\begin{array}{l}\text { Employment, industry (\% of total } \\
\text { employment) }\end{array}$ & 28.46 & 28.41 & 1.18 & 1.40 \\
\hline $\begin{array}{l}\text { Employment, services (\% of total } \\
\text { employment) }\end{array}$ & 62.39 & 62.41 & 3.30 & 10.88 \\
\hline $\begin{array}{l}\text { Agricultural efficiency (value added / } \\
\text { employment) }\end{array}$ & 0.49 & 0.45 & 0.10 & 0.01 \\
\hline
\end{tabular}

\begin{tabular}{|l|c|c|c|c|}
$\begin{array}{l}\text { Industrial Efficiency (Value Added / } \\
\text { Employment) }\end{array}$ & 1.07 & 1.07 & 0.06 & 0.00 \\
\hline $\begin{array}{l}\text { Service Efficiency (Value Added / } \\
\text { Employment) }\end{array}$ & 0.85 & 0.84 & 0.04 & 0.00 \\
\hline Integral Efficiency & 0.44 & 0.41 & 0.09 & 0.01 \\
\hline
\end{tabular}

Analysis revealed consistently low performance indicators of industry and services and critical of agriculture. A significant factor limiting economic growth is the slowdown in productivity growth that more is due to the critical values of agriculture efficiency, which, in turn, dramatically changes integral effectiveness of the Russian economy. After a stable increase in efficiency of agriculture in 2013 -2018 a sharp decline is expected both in agriculture and in the integral indicator of the economy structure efficiency.

Trade. Retrospective analysis and forecast of trade performance dynamics (imports and exports of goods and commercial services, merchandise trade and commercial services, current account balance) (Table III) allowed to reveal excess of goods and commercial services volatile export over their stable import and considerable excess of volatile trade of goods over stable trade of commercial services.

TABLE III. TRADE, 2000-2020

\begin{tabular}{|l|l|l|l|l|}
\hline Indicators & AV & Me & SD & $6^{2}$ \\
\hline Import of goods and commercial services & 21.76 & 21.36 & 1.45 & 2.09 \\
\hline Exports of goods and commercial services & 32.06 & 31.44 & 5.06 & 25.64 \\
\hline Trade of goods & 45.10 & 45.97 & 5.90 & 34.79 \\
\hline Trade of commercial services & 8.72 & 8.91 & 1.07 & 1.16 \\
\hline Current account balance & 7.08 & 6.26 & 4.15 & 17.20 \\
\hline
\end{tabular}

As a result, the current dynamics of trade led to volatility of the low level of current account balance.

Therefore, taking into account the dominant efficiency of industry (see above) the main factor of trade activity is export of industrial goods which after the maximum value in 2018 should keep both the dominant position and volatility.

Foreign direct investment. Retrospective analysis and forecasting of foreign direct investment indicators dynamics (balance of flows and stocks of foreign direct investment (inflow-outflow), efficiency in the balance (flows/stocks) (Table 4) revealed volatility - at low values in the balance of direct investment flows, at average values - in the inventory balance of direct investment. This situation has determined differences in efficiency by balance (flows/stocks).

TABLE IV. FOREIGN DIRECT INVESTMENTS, 2000-2020

\begin{tabular}{|l|l|l|l|l|}
\hline Indicators & $\mathrm{AV}$ & $\mathrm{Me}$ & $\mathrm{SD}$ & $6^{2}$ \\
\hline $\begin{array}{l}\text { FDI flows, imports (\% of gross fixed } \\
\text { capital formation) }\end{array}$ & 10.85 & 10.32 & 4.77 & 22.80 \\
\hline $\begin{array}{l}\text { FDI flows, export (\% of gross fixed } \\
\text { capital formation) }\end{array}$ & 11.31 & 11.96 & 3.49 & 12.16 \\
\hline FDI stocks, imports (\% of GDP) & 22.24 & 20.33 & 6.56 & 43.05 \\
\hline FDI stocks, export (\% of GDP) & 18.61 & 17.73 & 5.04 & 25.39 \\
\hline $\begin{array}{l}\text { Balance of FDI flows, inflow and outflow } \\
\text { (\% of gross fixed capital formation) }\end{array}$ & -0.46 & 0.28 & 3.45 & 11.93 \\
\hline $\begin{array}{l}\text { Balance of FDI stocks, inflow-outflow (\% } \\
\text { of GDP) }\end{array}$ & 3.62 & 3.81 & 2.73 & 7.47 \\
\hline Balance efficiency, flows / stocks & 0.61 & 0.08 & 1.83 & 3.34 \\
\hline
\end{tabular}

There should be noted the positive maxima of efficiency in the balance of $2008-2009$ and 2014-2015. In 2008-2009 
high efficiency values were achieved due to the total (flow and reserves) inflow of foreign direct investment, and in 20142015 - due to outflow. A negative component is the decline in the FDI stock balance since 2016 and the lack of growth in the balance of FDI flows which led to a "zero" efficiency of FDI in the balance of $2017-2020$.

Financial system. Analysis of retrospective and forecast dynamics of the financial system indicators (S\&P (global stock indices), growth rates of total reserves (including gold), revenues and expenditures of the public sector, tax revenues to the public sector, surplus/deficit of public sector funds) (Table V) allowed to reveal volatility - the average values of S\&P and high growth rates of total reserves including gold.

TABLE V. FINANCIAL SYSTEM, 2000-2020

\begin{tabular}{|l|l|l|l|l|}
\hline Indicators & $\mathrm{AV}$ & $\mathrm{Me}$ & $\mathrm{SD}$ & $6^{2}$ \\
\hline $\begin{array}{l}\text { S\&P global stock indices (change } \\
\text { in \% per annum) }\end{array}$ & 20.22 & 21.94 & 42.19 & 1779.69 \\
\hline $\begin{array}{l}\text { Total reserves, including gold } \\
\text { (millions of USD) }\end{array}$ & 131.71 & 131.26 & 36.70 & 1347.15 \\
\hline Public sector revenues (\% of GDP) & 27.96 & 27.58 & 2.47 & 6.09 \\
\hline $\begin{array}{l}\text { Public sector expenditures (\% of } \\
\text { GDP) }\end{array}$ & 23.79 & 22.76 & 3.65 & 13.35 \\
\hline $\begin{array}{l}\text { Public sector tax revenues (\% of } \\
\text { GDP) }\end{array}$ & 14.08 & 13.74 & 1.91 & 3.63 \\
\hline $\begin{array}{l}\text { Public sector cash surplus/deficit } \\
\text { (\% of GDP) }\end{array}$ & 3.07 & 3.05 & 3.88 & 15.09 \\
\hline
\end{tabular}

At the same time revenues and expenditures of the public sector and tax revenues to the public sector are comparable in terms of quality of dynamics.

A distinctive feature of the Russian financial system is the opportunistic growth of total reserves (including gold) against the background of $S \& P$ volatility while maintaining stable parameters of revenues and expenditures of the public sector and tax revenues to the public sector with natural growth by the average (median) value of the surplus of public sector funds.

Ease of doing business and perception of corruption. The index of ease of doing business (Ease of Doing Business Index) prepared by the World Bank for ease of entrepreneurial activity comparison between countries based on annual data of ten internal indicators: starting a business; work with construction permits; getting electricity; registering property; getting credit; protecting investors; paying taxes; international trade; enforcing contracts; closing a company. Active decline of the ease of doing business index (Table 6) reflects the desire to liberalize the Russian market. In 2018 Russia is ahead of France in the ease of doing business rating ( 31 and 32 respectively) but is significantly behind the United States (8th place).

TABLE IV. EASE OF DOING BUSINESS AND PERCEPTION OF CORRUPTION, 2005-2018.

\begin{tabular}{|l|l|l|l|l|}
\hline Indicators & $\mathrm{AV}$ & $\mathrm{Me}$ & $\mathrm{SD}$ & $6^{2}$ \\
\hline Ease of Doing Business Index (rating) & 84.79 & 94.00 & 34.66 & 1201.57 \\
\hline $\begin{array}{l}\text { Corruption Perception Index } \\
\text { (assessment) }\end{array}$ & 27.50 & 26.50 & 5.35 & 28.58 \\
\hline
\end{tabular}

The corruption perception index (Corruption Perception Index CPI) from 0 (highest level of corruption) to 100 (absence of corruption) compiled by the international NGO Transparency International based on several independent polls involving international financial and human rights experts, including those from Asian and African development banks, the World Bank and the American organization Freedom House.

Russia demonstrates steady growth of the corruption perception index since 2005. In 2018 Russia is on the 136th place ahead of Lebanon and behind Iran.

Thus in the Russian economy there is an active liberalization of market and the corrupt structures are the beneficiaries of it.

Structural analysis of the Russian economy ability to generate profit includes cluster, neural network and nonparametric analysis of the previously estimated set (see above) indicators.

Cluster analysis. Calculation was carried out using SPSSStatistics (hierarchical cluster analysis; average distance between clusters, squared Euclidean distance) according to the Organization for Economic Cooperation and Development, OECD [17]. Analysis revealed the following clusters:

- population growth rate and agricultural efficiency, balance sheet efficiency, FDI flow balance, etc.;

- consumer prices and unemployment;

- unemployment and employment (agriculture), current account balance;

- labor productivity growth rates and growth rates of total reserves (including gold);

- value added (agriculture) and FDI stock balance (inflows-outflows), public sector cash surplus/deficit, etc.

Cluster-forming factors are as follows: population growth rate; consumer prices; unemployment rate; productivity growth rates; value added; employment (agriculture and industry); efficiency (agriculture and industry); imports of goods and commercial services; flows and stocks (FDI, imports).

Neural network analysis. As a result of analysis (Multilayer perception, batch training) there is identified a hierarchy of indicators importance among which the following (having importance of over $50 \%$ ) should be highlighted - employment (services and industry), growth rate of labor productivity (value added services), imports of goods and commercial services, reserves, FDI, efficiency of agriculture, integrated efficiency, growth of total reserves (including gold), consumer prices. Adjustment of cluster analysis results according to the importance of indicators allowed to determine the weighty clusters: productivity growth rates and growth rates of total reserves (including gold); employment (industry) and public sector income; value added (services) and employment (services), trade of goods; import of goods and commercial services and public sector expenditures, FDI stocks (import); agricultural efficiency and integrated efficiency, industrial efficiency; FDI stocks (import) and FDI stocks (export); consumer prices and unemployment rate, FDI flows (import), GDP deflator. 
current account deficits. When the boom begins, the gap is positive, and the Central Bank can accumulate reserves and sterilize capital inflows. However, later, when optimism fades, the gap inevitably becomes negative leading to depletion of reserves and decrease of exchange rate [22].

The negative component in The Russian economy is the reduction of inventory balance FDI since 2016 and lack of growth in the balance of FDI flows which led to "zero" efficiency of FDI in the balance 2017 - 2020, which to a remarkable degree shows closeness to crisis $2014-2015$. The Russian government is focusing on fiscal policy making it difficult to ensure consistency between actions at the foreign exchange rate and policies to reduce fiscal imbalances to achieve the desired level of the real exchange rate and equilibrium of the of payments balance [23].

Russian financial system demonstrates a market-oriented growth of total reserves (including gold) against the background of S\&P volatility maintaining stable parameters of revenues and expenditures of the public sector and tax revenues to the public sector with natural growth by the average (median) value, the surplus of public sector funds. Against the background of decline in the index of ease of doing business (for greater liberalization of Russian market) and relatively stable growth of corruption perception index there are implicitly distinguished the Public corporations with affiliated entities - the Ministry of Finance and the Central Bank that define priorities of The Russian economy structure.

\section{CONCLUSION}

Current structure of modern Russian economy makes it possible to distinguish the systemic ability of The Russian economy to generate profits by changing the dynamics of GDP deflator; value added (services); employment (services); FDI stocks (import and export); import of goods and commercial services; FDI flows (import); consumer prices; public sector expenditures; growth rates of total reserves (including gold); growth rates of labor productivity; trade of goods and unemployment.

In the selected format of abilities there are shaped certain managerial decisions on curbing the growth of unemployment, increase of efficiency of industry, services and agriculture, ensuring the balance of income and expenditure of the public sector and tax revenues in the public sector, etc.

The Ministry of Finance and the Central Bank of Russia play a special role in realization of these abilities. They are of considerable interest to American corporate governance as the main beneficiaries of the current structure of The Russian economy.

\section{References}

[1] V. Mau, A. Ulyukaev. "Global crisis and challenges for Russian economic development". Russian Journal of Economics, 2015, vol. 1, iss. 1, pp. 429. https://doi.org/10.1016/j.ruje.2015.05.003

[2] V. Mau. "Lessons in stabilization and prospects for growth: Russia's economic policy in 2016". Russian Journal of Economics, 2017, vol. 3, iss. 2, pp. 109-128. https://doi.org/10.1016/j.ruje.2017.06.001

[3] K. Ito. "Dutch disease and Russia". International Economics, 2017, vol. 151, pp. 66-70. https://doi.org/10.1016/j.inteco.2017.04.001 import, and output and savings are growing less than investment, it results in a current account deficit. Exchange rate depends on the gap between total capital inflows and total 
[14] A. Sharma, R. Pal. "Nash equilibrium in tax and public investment competition". International Review of Economics \& Finance, 2019, vol. 62, pp. 106-120. https://doi.org/10.1016/j.iref.2019.03.005

[15] S. C. Mortal, M. J. Schill. "The role of firm investment in momentum and reversal". Journal of Empirical Finance, 2018, vol. 48, pp. 255-278. https://doi.org/10.1016/j.procir.2019.02.126

[16] "World Bank and the International monetary Fund". The Conference Board Total Economy Database. http://www.conference-board.org

[17] "The Organization for Economic Cooperation and Development". OECD.Stat. https://stats.oecd.org

[18] V. Smirnov, V. Semenov, E. Kadyshev, A. Zakharova, A. Babaeva. "Management of Employment Promotion Institution In Russia". The European Proceedings of Social \& Behavioural Sciences (SCT 2018), 2019, no. 134, pp. 1157-1165. https://dx.doi.org/10.15405/epsbs.2019.03.02.134

[19] V.V. Smirnov, D.G. Osipov, A.A. Babaeva, E.V. Grigorieva, E.F. Perfilova "Parity of innovation and digital economy in the Russian management system". Proceedings of the 1st International Scientific Conference "Modern Management Trends and the Digital Economy: from Regional Development to Global Economic Growth" (MTDE 2019). Pp. 22-27. https://doi.org/10.2991/mtde-19.2019.5

[20] V. A. Canto, A. Wiese. "Chapter 21 - Trade Policy, Protectionism, and Currency Manipulation. Economic Disturbances and Equilibrium in an Integrated Global Economy". Investment Insights and Policy Analysis, 2018, pp. 201-207. https://doi.org/10.1016/B978-0-12-813993-6.00021-0

[21] D. Leblang. "Devalue or to Defend? The Political Economy of Exchange Rate Policy”. International Studies Quarterly, 2003, vol. 47, iss. 4, 2003, pp. 533-559. https://doi.org/10.1046/j.0020-8833.2003.00278.x

[22] N. A. Müller-Plantenberg. "Currency Flows and Currency Crises". CESifo Economic Studies, 2017, vol. 63, iss. 2, pp. 182-209, https://doi.org/10.1093/cesifo/ifw021

[23] M. S. Khan, J. S. Lizondo. "Devaluation, Fiscal Deficits, and the Real Exchange Rate". The World Bank Economic Review, 1987, vol. 1, iss. 2, pp. 357-374, https://doi.org/10.1093/wber/1.2.3571 